KONSTRUKTIVISME, Vol. 10, No. 2, Juli 2018

p-ISSN: 1979-9438; e-ISSN: 2442-2355

FKIP Universitas Islam Balitar, Blitar

Http://konstruktivisme.unisbablitar.ejournal.web.id; Email: konunisba@gmail.com

\title{
AKTIVITAS SISWA DALAM PEMBELAJARAN IPA KONSEP EKOSISTEM MELALUI PENERAPAN MODEL PEMBELAJARAN INKUIRI TERBIMBING DI SEKOLAH MENENGAH
}

\author{
Zuraida Usdek Wati \\ Guru IPA Terpadu SMPN 24 Banjarmasin \\ Email:idaprayitno63@gmail.com
}

ABSTRAK:

Pembelajaran IPA, khususnya materi ekosistem perlu tindak lanjut dalam perbaikan pembelajaran, sehingga dalam pembelajaran siswa diharapkan dapat berperan secara aktif dalam kegiatan belajar mengajar. Hal ini juga berguna dalam meningkatkan hasil belajar biologi pada materi ekosistem. Untuk mengatasi kesulitan dalam pembelajaran salah satu pertimbangannya yaitu memperbaiki kemampuan siswa dalam proses pembelajaran dan meningkatkan kemampuan siswa dalam menemukan jawaban. Salah satu cara yang dapat ditempuh adalah dengan menggunakan pembelajaran inkuiri terbimbing saat KBM berlangsung, atau siswa terlibat langsung dalam mengajukan pertanyaan, mencari informasi dan melakukan penyelidikan. Penelitian ini bertujuan untuk meningkatkan aktivitas siswa kelas VII-C SMPN 25 Banjarmasin menggunakan model inkuiri terbimbing pada materi ekosistem. Penelitian ini adalah Penelitian Tindakan Kelas (PTK) yang dirancang dalam 2 siklus pembelajaran, dengan masing-masing siklus terdiri dari 2 kali pertemuan. Subjek penelitian ini semua siswa kelas VII-C SMPN 25 Banjarmasin tahun ajaran 2014/2015. Teknik pengumpulan data yang digunakan meliputi pemberian tes, observasi dan angket. Data yang diperoleh dianalisis secara kualitatif dan kuantitatif. Hasil penelitian menunjukkan aktivitas siswa dapat ditingkatkan dengan menggunakan pembelajaran inkuiri terbimbing.

Kata Kunci: aktivitas siswa, ekosistem, inkuiri terbimbing, sekolah

\section{ABSTRACT:}

The learning of Science, especially ecosystem material needs to be followed up in improving the learning, so that the students are expected to participate actively in learning and teaching process. 
Zuraida Usdek Wati. 2018. Aktivitas Siswa dalam Pembelajaran IPA Konsep Ekosistem melalui Penerapan Model Pembelajaran Inkuiri Terbimbing di Sekolah Menengah. Konstruktivisme, 10 (2): 231-238

This is also useful in improving the result of Biology learning in ecosystem material. To solve the difficulties of learning, one of considerations is improving the student's ability in learning process and to find the answers. One way that can be taken is to use guided inquiry learning during teaching learning takes place. Or students aredirectly involved in asking questions, searching information and conducting aninvestigation. This research is aimed at improving students' activity of garde VII-C SMPN 25 Banjarmasin usingguided inquiry learning on Ecosystem material. This study is a Classroom Action Research (CAR) which is designed in two learning cycles, with each cycle consisting of 2 meetings. The subjects of this study were all students of class VII - C of SMP 25 Banjarmasin in academic year2014/2015. Data collection techniques used including the provision of tests, observations and questionnaires. The data obtained were analyzed qualitatively and quantitatively. The results of the study show that students' activity can be improved by using guided inquiry learning.

Keywords: students' activity, ecosystem, guided inquiry, school

\section{PENDAHULUAN}

Mata pelajaran IPA Terpadu yang dipelajari di Sekolah Menengah Pertama (SMP), pada kelas VII mempelajari tentang konsep Ekosistem yang memuat bahan tentang makhluk hidup dan segala aspek kehidupan seharihari mengenai alam sekitar. Proses pembelajaran tentang ekosistem, ditentukan oleh bagaimana seorang guru menyajikan dan menyampaikan materi pembelajaran dengan baik dan menggunakan metode serta strategi yang tepat saat digunakan di kelas. Dalam kegiatan belajar mengajar (KBM), metode mengajar diperlukan oleh guru dan penggunaanya bervariasi sesuai dengan tujuan yang ingin dicapai setelah proses pengajaran berakhir.

Pembelajaran IPA, khususnya pada pembelajaran ekosistem perlu tindak lanjut dalam perbaikan pembelajaran, sehingga dalam pembelajaran siswa diharapkan dapat berperan secara aktif dalam kegiatan belajar mengajar, guna meningkatkan hasil belajar biologi pada materi ini. Untuk mengatasi kesulitan-kesulitan dalam pembelajaran tersebut, salah satu pertimbangannya yaitu memperbaiki kemampuan siswa dalam proses pembelajaran dan meningkatkan hasil belajar sehingga mampu meningkatkan kemampuan siswa dalam menemukan jawaban. Salah satu pembelajaran 
Zuraida Usdek Wati. 2018. Aktivitas Siswa dalam Pembelajaran IPA Konsep Ekosistem melalui Penerapan Model Pembelajaran Inkuiri Terbimbing di Sekolah Menengah.

Konstruktivisme, 10 (2): 231-238

tersebut adalah dengan menggunakan model inkuiri terbimbing yang berarti siswa ikut serta, atau terlibat dalam mengajukan pertanyaan-pertanyaan, mencari informasi dan melakukan penyelidikan.

Hasil observasi pada kelas VII-C SMPN 25 Banjarmasin memperlihatkan masih kurangnya siswa dalam berpikir kritis dan logis pada saat proses pembelajaran berlangsung sehingga menganggu hasil belajar siswa. Diketahui juga adanya siswa yang kurang aktif saat pembelajaran berlangsung. Selain itu diperoleh informasi bahwa hasil belajar siswa masih tergolong rendah. Hal ini dapat dilihat dari nilai ulangan harian siswa, yaitu $45 \%$ siswa yang belum mencapai Kriteria Ketuntasan Minimum Sekolah. Kriteria Ketuntasan Minimum di SMPN 25 Banjarmasin adalah 70.

Peneliti memilih SMPN 25 Banjarmasin sebagai objek penelitian karena berdasarkan dari hasil observasi, pembelajaran di SMPN 25 Banjarmasin umumnya menggunakan pembelajaran yang berpusat pada guru, sehingga siswa berperan kurang aktif dalam proses pembelajaran, serta belum pernah melaksanakan pembelajaran dengan menggunakan model pembelajaran inkuiri terbimbing yaitu siswa menemukan sendiri permasalahan yang terjadi dengan bimbingan dari guru. Berdasarkan observasi pula pembelajaran inkuiri terbimbing dapat diterapkan di SMPN 25 Banjarmasin karena didukung oleh semangat guru yang bersedia mempelajari berbagai macam pembelajaran yang belum pernah diterapkan dalam pembelajaran sebelumnya.

Inkuiri terbimbing merupakan bagian inti dari kegiatan pembelajaran berbasis kontekstual. Pengetahuan dan keterampilan yang diperoleh siswa diharapkan bukan hasil mengingat seperangkat fakta-fakta, tetapi hasil dari menemukan sendiri. Guru harus selalu merancang kegiatan yang merujuk pada kegiatan menemukan, apapun materi yang diajarkan (Trianto 2011: 109).

\section{METODE PENELITIAN}

Subjek penelitian adalah siswa kelas VII-C SMPN 25 Banjarmasin, dengan jumlah siswa 39 orang. Penelitian ini dilakukan pada semester genap tahun ajaran 2014/2015, bulan Mei-Juni 2015 dan bertempat di kelas VII-C SMPN 25 Banjarmasin. Sebagai pertimbangan memasuki siklus berikutnya dan digunakan pula sebagai pertimbangan keberhasilan pembelajaran, maka pertimbangan yang digunakan untuk indikator aktivitas siswa dalam pembelajaran adalah mencapai $80 \%$ siswa aktif dalam pembelajaran. Penelitian ini direncanakan dalam 2 siklus dimana tiap siklus ada 2 kali pertemuan dan setiap siklusnya ada 4 tahap, diantaranya adalah perencanaan (planning), pelaksanaan tindakan (action) dan pengamatan (observation), evaluasi dan refleksi (reflection). 
Zuraida Usdek Wati. 2018. Aktivitas Siswa dalam Pembelajaran IPA Konsep Ekosistem melalui Penerapan Model Pembelajaran Inkuiri Terbimbing di Sekolah Menengah. Konstruktivisme, 10 (2): 231-238

Instrumen pengumpulan data dalam penelitian ini adalah lembar observasi yang digunakan untuk memperoleh data mengenai aktivitas siswa dalam menggunakan inkuiri terbimbing. Analisis data yang digunakan dalam penelitian ini menggunakan tabel kriteria penilaian aktivitas siswa.

Tabel 1. Kriteria Penilaian

\begin{tabular}{cc}
\hline Persentase $(\%)$ & Kualifikasi \\
\hline $90-100$ & Baik sekali (BS) \\
$80-89$ & Baik (B) \\
$70-79$ & Cukup (C) \\
$<70$ & Kurang (K) \\
\hline Sumber: Winataputra (2008: 17$).$
\end{tabular}

Tabel 1. di atas adalah tabel kriteria penilaian dalam angka bentuk persentase (\%) dan konversinya ke kualifikasi huruf dimana diharapkan nantinya penelitian ini akan menghasilkan nilai aktivitas siswa yang meningkat dari siklus I ke siklus II.

\section{HASIL DAN PEMBAHASAN}

Hasil penelitian terhadap pelaksanaan tindakan kelas yang terdiri atas 2 siklus dengan 4 kali pertemuan, pada siswa kelas VII-C SMPN 25 Banjarmasin pada konsep Ekosistem dengan menggunakan pembelajaran inkuiri terbimbing. Data yang diperoleh yaitu kuantitatif dan kualitatif. Data kualitatif dalam kegiatan pembelajaran menggunakan inkuiri terbimbing meliputi observasi terhadap aktivitas yang dilakukan oleh siswa selama proses pembelajaran berlangsung.

\section{Aktivitas Siswa dalam Pembelajaran Siklus I Pertemuan 1.}

Aktivitas siswa pada pembelajaran siklus I pertemuan 1 dapat dilihat seperti pada Tabel 2. berikut ini.

Tabel 2. Aktivitas Siswa dalam Pembelajaran pada Siklus I Pertemuan 1

\begin{tabular}{|c|c|c|c|c|c|c|}
\hline \multirow{2}{*}{ No. } & \multirow{2}{*}{ Kegiatan siswa } & \multicolumn{5}{|c|}{ Skor } \\
\hline & & 1 & 2 & 3 & 4 & 5 \\
\hline 1. & $\begin{array}{l}\text { Kegiatan Awal } \\
\text { - Memperhatikan guru } \\
\text { - Mendegarkan dan menjawab pertanyaan } \\
\text { - Mendengarkan } \\
\text { - Menjawab soal pretest }\end{array}$ & & $\begin{array}{l}\sqrt{ } \\
\sqrt{ }\end{array}$ & $\sqrt{ }$ & & \\
\hline
\end{tabular}


Zuraida Usdek Wati. 2018. Aktivitas Siswa dalam Pembelajaran IPA Konsep Ekosistem melalui Penerapan Model Pembelajaran Inkuiri Terbimbing di Sekolah Menengah. Konstruktivisme, 10 (2): 231-238

\begin{tabular}{|c|c|c|c|c|c|c|}
\hline \multirow{2}{*}{ No. } & \multirow{2}{*}{ Kegiatan siswa } & \multicolumn{5}{|c|}{ Skor } \\
\hline & & 1 & 2 & 3 & 4 & 5 \\
\hline 2. & $\begin{array}{l}\text { Kegiatan inti } \\
\text { - Mendengarkan } \\
\text { - Membentuk kelompok diskusi } \\
\text { - Melakukan pengamatan } \\
\text { - Merumuskan hipotesis } \\
\text { - Mengumpulkan data dan Tanya jawab } \\
\text { - Menganalisis data } \\
\text { - Merumuskan kesimpulan } \\
\text { - Mempresentasikan hasil diskusi }\end{array}$ & & $\begin{array}{l}\sqrt{ } \\
\sqrt{ }\end{array}$ & $\begin{array}{l}\sqrt{ } \\
\sqrt{ } \\
\sqrt{ }\end{array}$ & & \\
\hline 3. & $\begin{array}{l}\text { - Membuat kesimpulan dan menutup } \\
\text { pelajaran } \\
\text { - Menjawab soal post test }\end{array}$ & & $\sqrt{ }$ & $\sqrt{ }$ & & \\
\hline
\end{tabular}

Keterangan:

Lanjutan Tabel 2.......
1. sangat kurang
3. Cukup aktif
5. Sangat aktif
2. kurang aktif
4. Aktif

Pada Tabel 2 dapat terlihat bahwa kegiatan/aktivitas siswa yang masih mendapat skor 2 (kurang aktif) ada di lima kegiatan yakni, memperhatikan guru, mendengarkan, merumuskan hipotesis, menganalisis data, dan membuat kesimpulan serta menutup kegiatan pembelajaran di kelas. Untuk kegiatan lainnya telah mendapat skor 3 (cukup aktif).

\section{Aktivitas Siswa dalam Pembelajaran Siklus I Pertemuan 2.}

Aktivitas siswa pada pembelajaran siklus I pertemuan 1 dapat dilihat seperti pada Tabel 3. berikut ini.

Tabel 3. Aktivitas Siswa dalam Pembelajaran pada Siklus I Pertemuan 2

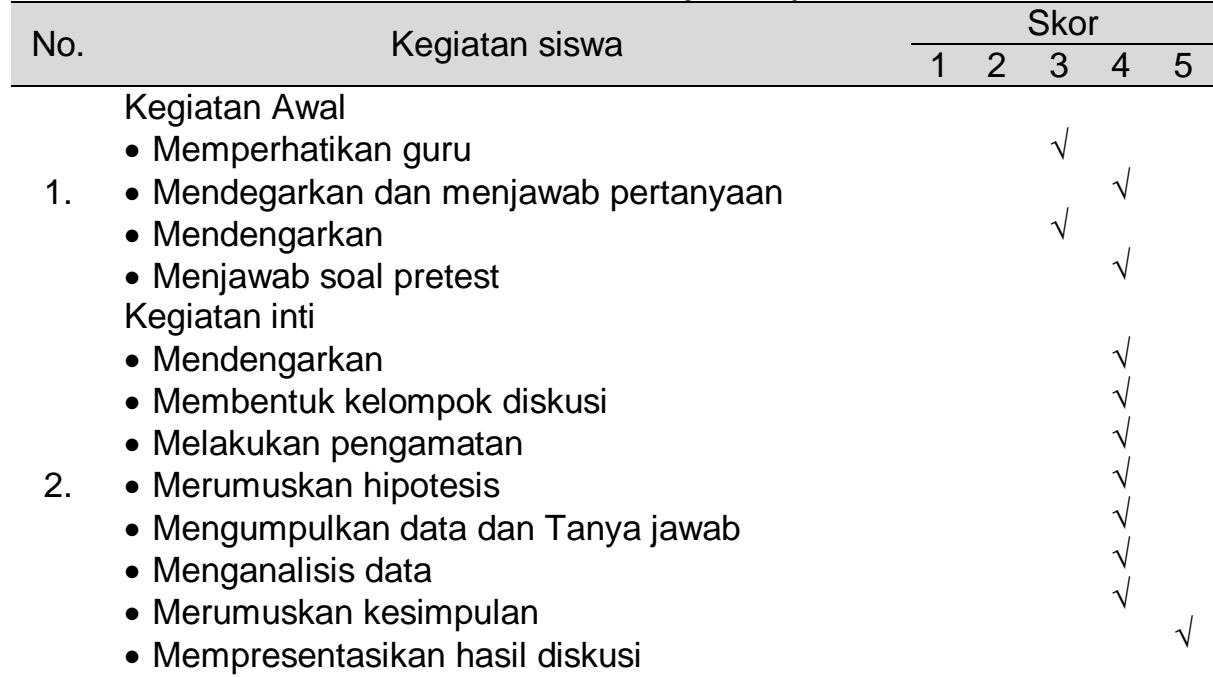


Zuraida Usdek Wati. 2018. Aktivitas Siswa dalam Pembelajaran IPA Konsep Ekosistem melalui Penerapan Model Pembelajaran Inkuiri Terbimbing di Sekolah Menengah.

Konstruktivisme, 10 (2): 231-238

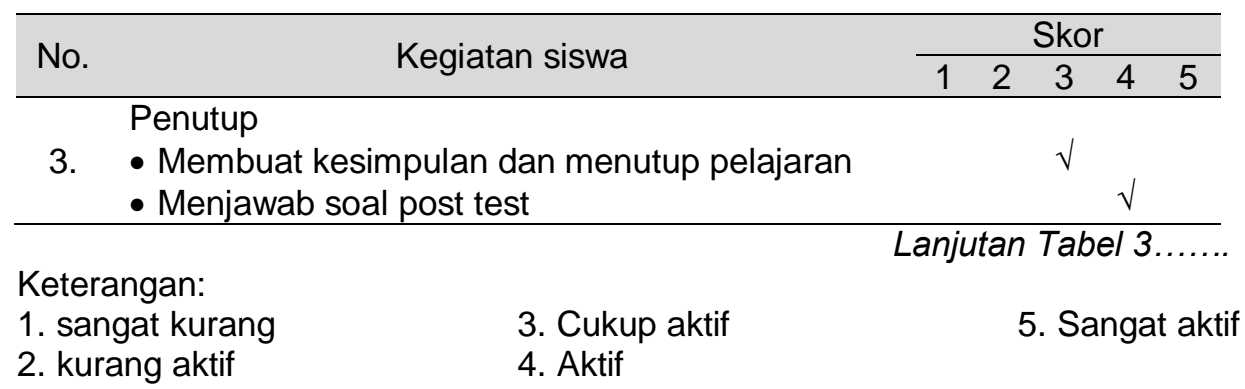

Pada Tabel 3 dapat terlihat bahwa kegiatan atau aktivitas siswa yang masih mendapat skor 3 (cukup aktif) ada di 3 kegiatan yakni, memperhatikan guru, mendengarkan dan membuat kesimpulan serta menutup kegiatan pembelajaran di kelas. Hal ini berarti untuk kegiatan merumuskan hipotesis dan menganalisis data telah mengalami kemajuan dengan mendapat skor sebesar 4 (aktif) dan untuk kegiatan mempresentasikan hasil diskusi mendapat nilai terbaik yakni skor 5 atau kategori sangat aktif.

\section{Aktivitas Siswa dalam Pembelajaran Siklus II Pertemuan 1.}

Aktivitas siswa pada pembelajaran siklus II pertemuan 1 dapat dilihat seperti pada Tabel 4. berikut ini.

Tabel 4. Aktivitas Siswa dalam Pembelajaran pada Siklus II Pertemuan 1

\begin{tabular}{|c|c|c|c|c|c|c|}
\hline \multirow{2}{*}{ No. } & \multirow{2}{*}{ Kegiatan siswa } & \multicolumn{5}{|c|}{ Skor } \\
\hline & & 1 & 2 & 3 & 4 & 5 \\
\hline 1. & $\begin{array}{l}\text { Kegiatan Awal } \\
\text { - Memperhatikan guru } \\
\text { - Mendegarkan dan menjawab pertanyaan } \\
\text { - Mendengarkan } \\
\text { - Menjawab soal pretest }\end{array}$ & & & & $\begin{array}{l}\sqrt{ } \\
\sqrt{ } \\
\sqrt{ } \\
\sqrt{ }\end{array}$ & \\
\hline 2. & $\begin{array}{l}\text { Kegiatan inti } \\
\text { - Mendengarkan } \\
\text { - Membentuk kelompok diskusi } \\
\text { - Melakukan pengamatan } \\
\text { - Merumuskan hipotesis } \\
\text { - Mengumpulkan data dan Tanya jawab } \\
\text { - Menganalisis data } \\
\text { - Merumuskan kesimpulan } \\
\text { - Mempresentasikan hasil diskusi }\end{array}$ & & & & $\begin{array}{l}\sqrt{ } \\
\sqrt{ } \\
\sqrt{ } \\
\sqrt{ } \\
\sqrt{ } \\
\sqrt{ } \\
\sqrt{ }\end{array}$ & $\sqrt{ }$ \\
\hline 3. & $\begin{array}{l}\text { Penutup } \\
\text { - Membuat kesimpulan dan menutup pelajaran } \\
\text { - Menjawab soal post test }\end{array}$ & & & & $\sqrt{ }$ & $\sqrt{ }$ \\
\hline
\end{tabular}

Keterangan:

$\begin{array}{lll}\text { 1. sangat kurang } & \text { 3. Cukup aktif } & \text { 5. Sangat aktif }\end{array}$

2. kurang aktif

4. Aktif 
Zuraida Usdek Wati. 2018. Aktivitas Siswa dalam Pembelajaran IPA Konsep Ekosistem melalui Penerapan Model Pembelajaran Inkuiri Terbimbing di Sekolah Menengah. Konstruktivisme, 10 (2): 231-238

Pada Tabel 4 dapat terlihat bahwa kegiatan atau aktivitas siswa tidak ada lagi yang mendapat skor 3 (cukup aktif). Hampir semua aktivitas atau kegiatan berada di skor 4 (aktif) dan bahkan ada dua kegiatan atau aktivitas yang berada pada skor 5 (sangat aktif) yakni mempresentasikan hasil diskusi dan menjawab soal post test. Hal ini berarti untuk dua kegiatan tersebut telah mengalami kemajuan dengan sangat baik karena berada di kategori sangat aktif.

\section{Aktivitas Siswa dalam Pembelajaran Siklus II Pertemuan 2.}

Aktivitas siswa pada pembelajaran siklus II pertemuan 1 dapat dilihat seperti pada Tabel 5. berikut ini.

Tabel 5. Aktivitas Siswa dalam Pembelajaran pada Siklus II Pertemuan 2

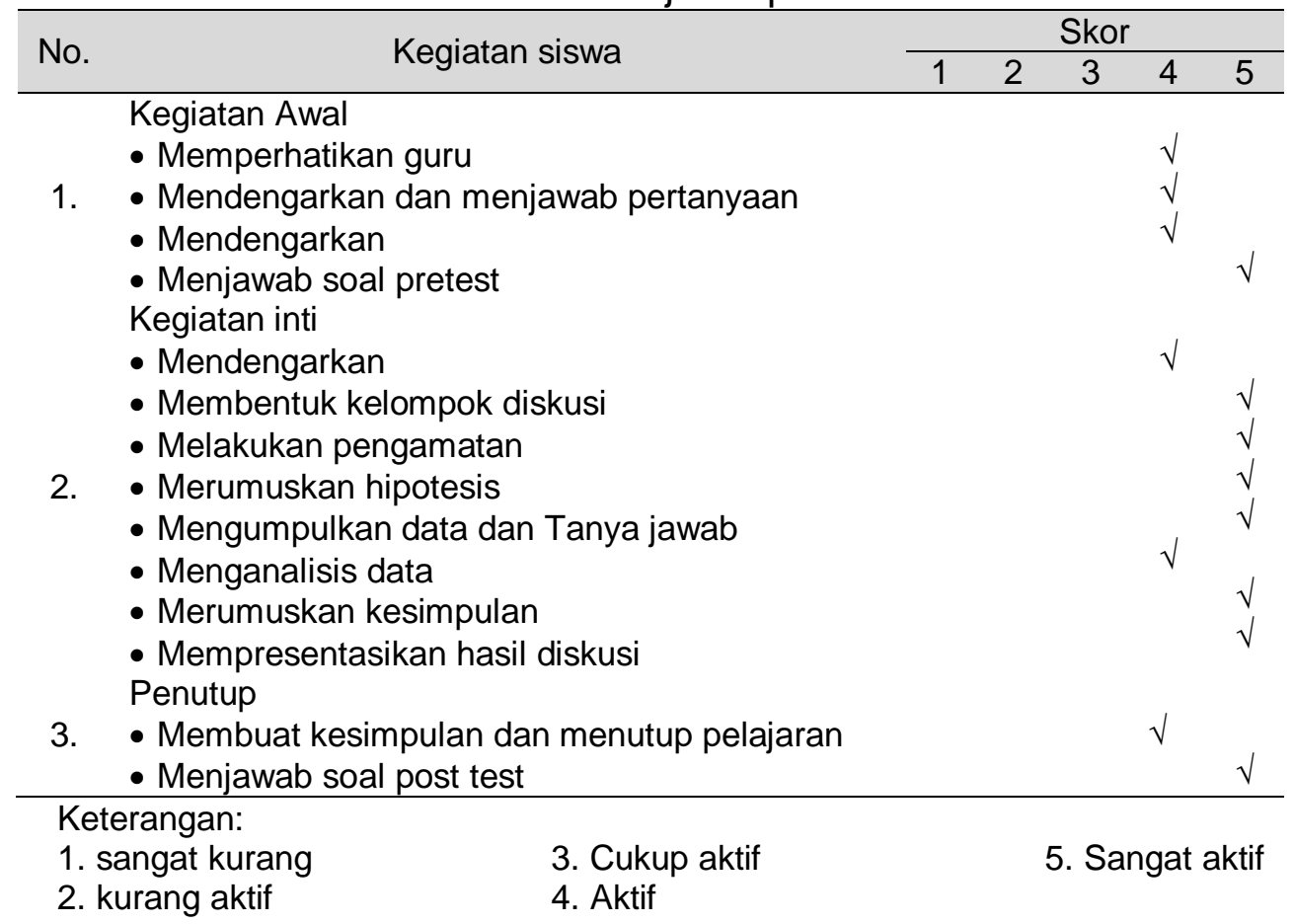

Pada Tabel 5 dapat terlihat bahwa kegiatan atau aktivitas siswa telah mengalami peningkatan yang cukup bagus dengan berada di skor 5 atau kategori sangat aktif. Ini artinya siswa mengalami perubahan dalam aktivitas atau kegiatannya menjadi jauh lebih baik dibandingkan dengan kegiatannya pada siklus I. Hanya ada enam kegiatan yang masih ada di kategori aktif atau skor 4 yakni kegiatan memperhatikan guru, mendengarkan dan menjawab pertanyaan, menganalisis data membuat kesimpulan, dan menutup pelajaran.

Aktivitas siswa di kelas pada pembelajaran dengan konsep Ekosistem melalui pembelajaran inkuiri terbimbing telah menunjukkan peningkatan dari 
Zuraida Usdek Wati. 2018. Aktivitas Siswa dalam Pembelajaran IPA Konsep Ekosistem melalui Penerapan Model Pembelajaran Inkuiri Terbimbing di Sekolah Menengah.

Konstruktivisme, 10 (2): 231-238

siklus I ke siklus II. Dari 14 parameter yang diamati semuanya mengalami peningkatan yang baik. Bahkan pada parameter 12 menunjukkan persentase yang sangat memuaskan sebesar $100 \%$ yaitu mempresentasikan hasil diskusi. Peningkatan ini diduga karena adanya upaya perbaikan pembelajaran setelah melakukan refleksi pada pembelajaran siklus I.

Bicara tentang peningkatan aktivitas siswa di setiap pertemuannya tidak terlepas dari semakin terbiasanya peserta didik dengan penggunaan model pembelajaran inkuiri terbimbing, sehingga meskipun tidak signifikan peningkatan itu tetap terjadi karena peserta didik berperan lebih aktif pada pembelajaran inkuiri. Salah satu kelebihan dengan inkuiri terbimbing adalah peserta didik dapat mempelajari heuristik (mengelola pesan atau informasi) dari penemuan, artinya bahwa cara untuk mempelajari teknik penemuan ialah dengan jalan memberikan kesempatan pada peserta didik untuk mengadakan penelitian sendiri, maka peserta didik akan memperoleh kepuasan untuk dirinya sendiri (Hamzah \& Uno 2013:31). Dari uraian tersebut dapat dikatakan bahwa pembelajaran menggunakan pembelajaran inkuiri terbimbing pada dasarnya dapat meningkatkan aktivitas siswa yang dikehendaki selama proses pembelajaran.

\section{SIMPULAN}

Aktivitas siswa dapat ditingkatkan dengan menggunakan pembelajaran inkuiri terbimbing. Parameter yang mengalami peningkatan yaitu parameter membaca LKS atau buku-buku yang relevan, merumuskan hipotesis berdasarkan LKS yang diberikan, bertanya kepada siswa lain atau kepada guru, dan membuat atau merumuskan kesimpulan dalam pembelajaran.

\section{DAFTAR RUJUKAN}

Hamzah dan Mohamad Nurdin Uno. 2013. Belajar dengan Pendekatan PAILKEM. Jakarta: Penerbit Bumi Aksara.

Trianto. 2011. Model-Model Pembelajaran Inovatif Berorientasi Konstruktivistik. Jakarta: Penerbit Prestasi Pustakaraya.

Winataputra, Udin S. 2008. Teori Belajar dan Pembelajaran. Jakarta. Universitas Terbuka. 